\title{
A NEW DISTRIBUTION RECORD FOR MACROBRACHIUM JELSKII (MIERS, 1877) IN ARGENTINA(DECAPODA, PALAEMONIDAE)
}

\author{
BY
}

\author{
PABLO A. COLLINS ${ }^{1}$ )
}

Instituto Nacional de Limnología, José Maciá 1933, CP 3016 Santo Tomé, Santa Fe, Argentina

The genus Macrobrachium Bate, 1888 has been known from Argentine freshwaters as represented by two species, M. borellii Nobili, 1896 and M. amazonicum Heller, 1862 (cf. Boschi, 1981; Pettovello, 1996).

Recent collections in northern Argentinean ponds and lagoons have revealed the presence of one additional species, which had not been reported from Argentina before.

This paper documents the occurrence of this species, M. jelskii, in South America, and extends its known range considerably southwards.

\section{Macrobrachium jelskii (Miers, 1877)}

Type locality. - Saint-Georges, French Guiana.

Material examined. - Twenty-three specimens, 13 males and 10 females; total lengths $29.0 \pm$ $4.60 \mathrm{~mm}$, cephalothorax lengths $12.7 \pm 2.39 \mathrm{~mm}$; Laguna Blanca $\left(25^{\circ} 10^{\prime} \mathrm{S} 58^{\circ} 11^{\prime} \mathrm{W}\right)$ Río Pilcomayo National Park, Argentina; 22.iii.1999. The material is deposited in the reference collection of the Invertebrate Department of the "Florentino Ameghino" Natural Museum of Santa Fe city, Argentina, catalogue $\mathrm{N}^{\circ}$ : MFA-ZI-N 367 .

Laguna Blanca. - The lake is a fluvial depression. It is located $1400 \mathrm{~km}$ from the sea. Some abiotic characteristics at the date of collection were: temperature: $20^{\circ} \mathrm{C}$; conductivity: $360 \mu \mathrm{Ohm} / \mathrm{cm}$; $\mathrm{pH}$ : 7.6 ; dissolved oxygen: $7.4 \mathrm{mg} / \mathrm{l}$; and Secchi disc reading: $34 \mathrm{~cm}$.

The dominant macrophyte are Thalia geniculata Linnaeus, Canna glauca Linnaeus, Cyperus prolixus Humboldt, Bonpland \& Kunth, Juncus pallescens Lamarck, Eichhornia crassipes Solms-Laubach, Pontederia cordata Linnaeus, Pistia stratiotes Linnaeus, and Azolla filiculoides Lamarck.

1) e-mail: inali@arcride.edu.ar 

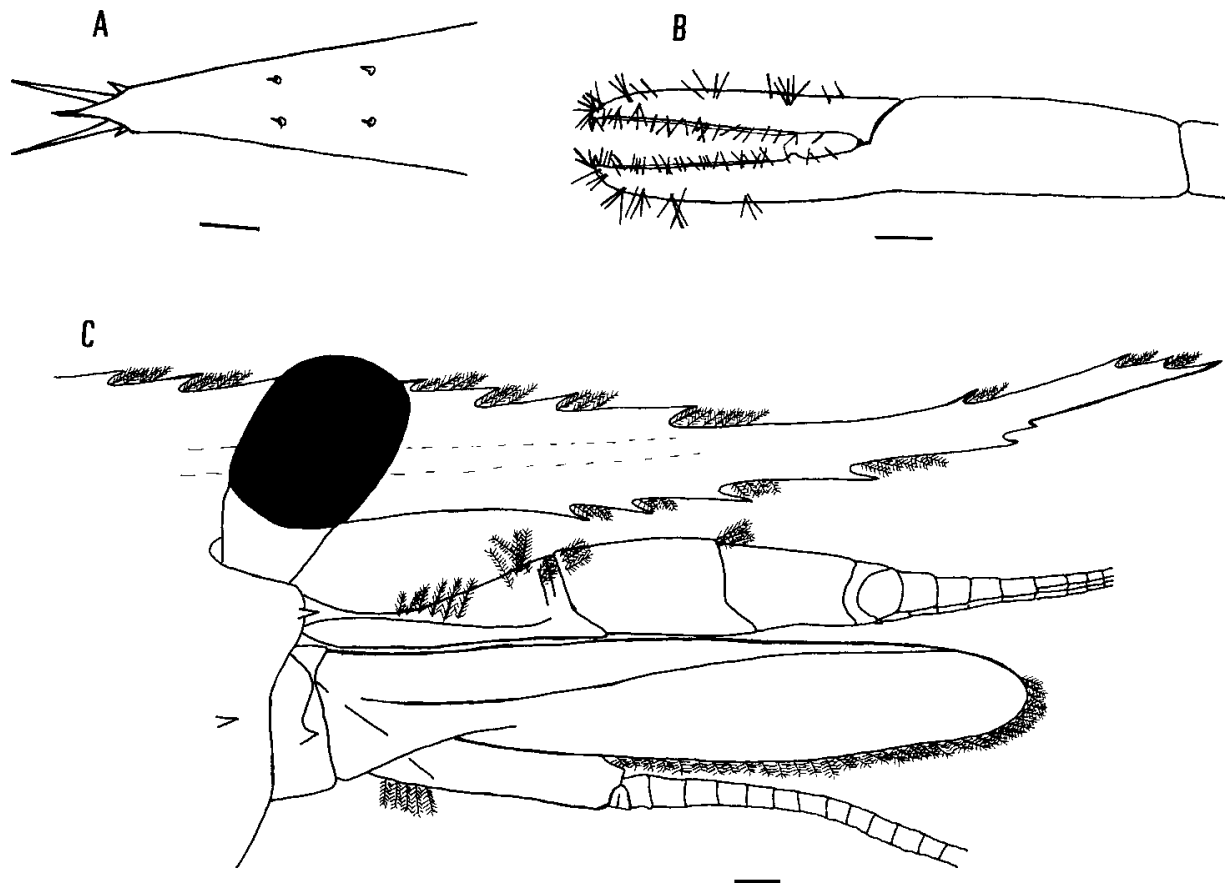

Fig. 1. Macrobrachium jelskii (Miers, 1877), adult male from Laguna Blanca, Río Pilcomayo Natural Park Argentina. A, dorsal view of the telson; B, lateral view of the left second chela; C, lateral view of the rostrum. Scale bars represent $0.3 \mathrm{~mm}$.

Previous records. - Venezuela, Trinidad, Costa Rica, Bolivia, the Guianas, Surinam, and Brazil (Parana do Jacaré, Lago Amaña, Rio Cuieiras, Rio Negro, Rio Urubaxi, Rio Preto da Eva, Lago Redondo)(Holthuis, 1966; Rodríguez, 1981; Kensley \& Walker, 1982).

Remarks. - In the specimens observed, the telson has a definite posterior margin that is drawn into a sharp median point, which is overreached by the inner pair of posterior telson spines (fig. 1A). The second chelae of the adult are equal or subequal, without tubercles along the cutting edges of the fingers (fig. 1B). The rostrum is longer than the scaphocerite, and its tip is curved upwards. The lower margin of the rostrum bears 5 or 6 teeth (fig. 1C). The remaining morphology is in agreement with existing descriptions (e.g., Holthuis, 1966; Chace \& Hobbs, 1969).

\section{REFERENCES}

Boschi, E. E., 1981. Decapoda Natantia. Fauna de Agua Dulce de la República Argentina, 26: $1-61$.

Chace, F. A., JR. \& H. H. Hobbs, JR., 1969. The freshwater and terrestrial decapod crustaceans of the West Indies with special reference to Dominica. U.S. natn. Mus. Bull., 292: 1-258. 
Holthuis, L. B., 1966. A collection of freshwater prawns (Crustacea Decapoda Palaemonidae) from Amazonia, Brazil, collected by Dr. G. Marlier. Bull. Inst. R. Sci. nat. Belgique, 42 (10): $1-11$.

Kensley, B. \& I. WAlker, 1982. Palaemonid shrimps from the Amazon basin, Brazil(Crustacea: Decapoda: Natantia). Smithson. Contrib. Zool., 362: i-iii, 1-28.

Miers, E. J., 1877. On a collection of Crustacea, Decapoda, and Isopoda, chiefly from South America, with descriptions of new genera and species. Proc. zool. Soc. London, 1877: 653679.

Pettovello, A. D., 1996. First record of Macrobrachiumamazonicum (Decapoda, Palaemonidae) in Argentina. Crustaceana, 69 (1): 113-114.

Rodríguez, G., 1981. Decapoda. In: S. H. Hurlbert, G. Rodríguez \& N. D. Santos (eds.), Aquatic biota of tropical South America, 1: Arthropoda: i-xii, 1-323. (San Diego State University, San Diego, California). 